\title{
Polish Dermatological Society Expert Group commentary on the management of Chlamydia trachomatis infections
}

\section{Komentarz Grupy Ekspertów Polskiego Towarzystwa Dermatologicznego dotyczący postępowania w zakażeniach Chlamydia trachomatis}

\author{
Agnieszka B. Serwin', Sławomir Majewski², Ryszard Żaba ${ }^{3}$, Joanna Maj ${ }^{4}$ Jacek Szepietowski ${ }^{4}$, Lidia Rudnicka \\ 'Department of Dermatology and Venereology, Medical University of Białystok, Poland \\ ${ }^{2}$ Chair and Department of Dermatology and Venereology, Medical University of Warsaw, Poland \\ ${ }^{3}$ Department of Dermatology and Venereology, Faculty of Health Sciences, Poznan University of Medical Sciences, Poznan, Poland \\ ${ }^{4}$ Department of Dermatology, Allergology and Venereology, Wroclaw Medical University, Wroclaw, Poland \\ ${ }^{5}$ Department of Dermatology, Medical University of Warsaw, Poland \\ IKlinika Dermatologii i Wenerologii Uniwersytetu Medycznego w Białymstoku, Polska \\ ${ }^{2}$ Katedra i Klinika Dermatologii i Wenerologii Warszawskiego Uniwersytetu Medycznego, Polska \\ 3Zakład Dermatologii i Wenerologii Wydziału Nauk o Zdrowiu Uniwersytetu Medycznego im. Karola Marcinkowskiego w Poznaniu, Polska \\ ${ }^{4}$ Klinika Dermatologii, Alergologii i Wenerologii Uniwersytetu im. Piastów Śląskich we Wrocławiu, Polska \\ ${ }^{5}$ Katedra i Klinika Dermatologiczna Warszawskiego Uniwersytetu Medycznego, Polska
}

Pełny tekst w języku polskim „Europejskie zalecenia dotyczące postępowania diagnostycznego i leczniczego w zakażeniach Chlamydia trachomatis 2015" dostępny w wersji on-line: https:/ /www.termedia.pl/ Europejskie-zalecenia-dotyczace-postepowania-diagnostycznego-i-leczniczego-w-zakazeniach-Chlamydiatrachomatis-2015,122,30273,0,0.html

Chlamydia (C.) trachomatis infections are the most commonly diagnosed sexually transmitted bacterial infection across Europe and worldwide. In 2014, a total of 396,128 cases of C. trachomatis infection were reported to the ECDC from 26 EU/EEA Member States, which represents a slight increase over the previous year. The mean incidence was 187 cases per 100,000 population. In six countries (Denmark, Iceland, Norway, Sweden, Finland and the United Kingdom) the incidence exceeded 200 cases per 100,000. Adolescents and young adults aged 15-24 years accounted for $63 \%$ of all cases. The male-to-female infection ratio was 0.7 [1].

In Poland urogenital chlamydial infections have been reported separately since 2015 (www.pzh.gov), even though a new form for reporting sexually transmitted diseases went into effect in July 2013 [2]. Previously, cases of non-specific urethritis were reported, however there are grounds to assume that the majority of them were chlamydial infections. Data reported to the ECDC show that the incidence of chlamydial infections in Poland between 2010 and 2014 ranged from 0.7 (2014) to 1.4 (2010) per 100,000 population [1]. The number most certainly does not reflect the
Zakażenia Chlamydia (C.) trachomatis są najczęściej diagnozowanym bakteryjnym zakażeniem przenoszonym drogą płciową w Europie i na świecie. W 2014 r. zgłoszono do ECDC z 26 krajów Unii Europejskiej i Europejskiego Obszru Gospodarczego 396128 przypadków zakażeń C. trachomatis, nieco więcej niż w roku poprzedzającym. Średnia zapadalność wyniosła 187 przypadków na 100000 ludności. W 6 krajach (Danii, Islandii, Norwegii, Szwecji, Finlandii i Wielkiej Brytanii) zapadalność przekroczyła 200 przypadków na 100000. Młodzież i młode osoby dorosłe (15-24 lat) stanowiły 63\% wszystkich zakażonych. Wskaźnik częstości występowania zakażeń u mężczyzn i kobiet wyniósł 0,7 [1].

W Polsce urogenitalne zakażenia chlamydialne są zgłaszane oddzielnie od 2015 r. (www.pzh.gov), chociaż nowy wzór formularza zgłaszania chorób przenoszonych drogą płciową wszedł w życie w lipcu 2013 r. [2]. Poprzednio zgłaszano nieswoiste zapalenia cewki moczowej i należy się domyślać, że zakażenia chlamydialne stanowiły ich większość. Według danych przesyłanych z Polski do ECDC zapadalność na zakażenia chlamydialne w naszym kraju w latach 2010-2014 wynosiła od 0,7 (2014) do 1,4 (2010) na 100000 [1]. Z pewnością nie odzwierciedla to rzeczywi- 
actual epidemiological situation, and results mainly from failure to perform laboratory tests and insufficient reportability.

Chlamydial infections, particularly in women, are frequently asymptomatic or produce only minimal symptoms. However, if they are left undiagnosed and untreated, they may lead to complications and permanent sequelae such as pelvic inflammatory disease, tubal factor infertility and ectopic pregnancy. Chlamydial infections may also cause reactive arthritis in patients of both sexes. During the last IUSTI (International Union against Sexually Transmitted Infections) Europe Congress (15-17 September 2016, Budapest) special attention was paid to the problem of frequent detection of rectal C. trachomatis infections in women (also in patients without a history of anal intercourse).

“2015 European guideline on the management of Chlamydia trachomatis infections" [3] was developed by European experts based on available medical evidence and approved by major European organizations and scientific societies representing dermatologists and venereologists, including the European Branch of the International Union against Sexually Transmitted Infections (IUSTI Europe); European Academy of Dermatology and Venereology (EADV); European Dermatology Forum (EDF); European Union of Medical Specialists (UEMS); European Centre for Disease Prevention and Control (ECDC) and WHO Regional Office for Europe. In the light of the above data, the Polish Dermatological Society Expert Group presents a translation of the most recent European guideline on the management of $C$. trachomatis infections and approves it for use in Poland with the following commentary:

\section{DIAGNOSTICS}

- The European guideline lists a number of indications for performing diagnostic laboratory tests to detect $C$. trachomatis infections; they should be expanded to include laboratory tests in the diagnostics of arthritis of unclear aetiology, particularly in young men.

- Molecular methods based on the amplification of bacterial genetic material (nucleic acid amplification tests - NAATs) are recommended to be used for laboratory diagnostics of C. trachomatis infections. Other methods, including direct immunofluorescence assays, may be used only when NAATs are unavailable. It is crucial to follow the recommendations from the manufacturer concerning collection, transportation, and storage of test specimens, and use internal and external quality control. The test specimens may be first- stej sytuacji epidemiologicznej, a wynika głównie z braku wykonywania badań laboratoryjnych oraz niedostatecznej zgłaszalności.

Zakażenia chlamydialne, zwłaszcza u kobiet, często przebiegają skąpoobjawowo lub bezobjawowo, a niezdiagnozowane i nieleczone mogą prowadzić do powikłań i trwałych następstw, takich jak zapalenie narządów miednicy mniejszej, niepłodność jajowodowa i ciąża pozamaciczna. U obu płci zakażenia chlamydialne mogą spowodować odczynowe zapalenie stawów. Na ostatnim Europejskim Kongresie International Union against Sexually Transmitted Infections - IUSTI (15-17 września 2016 r., Budapeszt) szczególną uwagę poświecono problemowi częstego wykrywania zakażeń C. trachomatis u kobiet w odbytnicy (także u pacjentek bez wywiadu kontaktów analnych).

„Europejskie zalecenia dotyczące postępowania diagnostycznego i leczniczego w zakażeniach Chlamydia trachomatis 2015" [3] zostały opracowane przez ekspertów europejskich na podstawie dostępnych dowodów medycznych i zaaprobowane przez następujące najważniejsze europejskie organizacje i towarzystwa naukowe reprezentujące dermatologów i wenerologów: Europejska Gałąź Międzynarodowej Unii do Zwalczania Zakażeń Przenoszonych Drogą Płciową (IUSTI Europe), Europejska Akademia Dermatologii i Wenerologii (EADV), Europejskie Forum Dermatologiczne (EDF), Unia Europejskich Specjalistów Medycznych (UEMS), Europejskie Centrum ds. Zapobiegania i Kontroli Chorób (ECDC) oraz Europejskie Biuro Światowej Organizacji Zdrowia. W świetle powyższych danych Grupa Ekspertów Polskiego Towarzystwa Dermatologicznego przedstawia tłumaczenie najnowszych europejskich zaleceń dotyczących zakażeń C. trachomatis oraz aprobuje je do stosowania w Polsce z następującym komentarzem:

\section{DIAGNOSTYKA}

- W wytycznych europejskich wymienia się liczne wskazania do diagnostyki laboratoryjnej w celu wykrycia zakażeń C. trachomatis; należałoby je dodatkowo rozszerzyć, zalecając wykonanie takich badań podczas diagnostyki zapaleń stawów o niewyjaśnionej etiologii, zwłaszcza u młodych mężczyzn.

- Zalecanymi metodami diagnostyki laboratoryjnej zakażeń C. trachomatis są metody molekularne oparte na amplifikacji materiału genetycznego bakterii (nucleic acid amplification tests - NAATs). Inne metody, w tym immunofluorescencja bezpośrednia, mogą być stosowane tylko wtedy, gdy NAATs są niedostępne. Należy przestrzegać zaleceń producenta dotyczących pobierania, transportu oraz przechowywania materiału do badań oraz uczestniczyć w wewnętrznej i zewnętrznej kontroli jakości. Materiałem do badań może być pierwsza porcja moczu u mężczyzn oraz 
void urine in men and vulvo-vaginal swabs in women (also self-collected).

- NAATs approved by the USA Food and Drug Administration and detecting different variants of $C$. trachomatis are recommended.

- Commercially available rapid point of care tests (POCT) are not recommended in Europe.

- Following the detection of C. trachomatis infection in the throat or rectum in homosexual men, further genotyping for LGV is recommended; such genotyping possibilities, however, are limited in Poland for now.

- The detection of antibodies against C. trachomatis in serum is not recommended either for screening or diagnosis of acute uncomplicated infections.

- A programme of voluntary screening for C. trachomatis infections, preferably annually, should be introduced in young ( $<25$ years of age) sexually active women and men.

- Patients with positive C. trachomatis test should be tested for gonorrhoea, syphilis and HIV.

\section{TREATMENT}

- An indication for therapy is the detection of C. trachomatis using recommended methods in specimens collected from the patient. Treatment is also recommended on epidemiological grounds (partner's infection) and in patients with symptoms of inflammation of the urogenital tract.

- First-line treatment regimens include a 7-day course of oral doxycycline $(2 \times 100 \mathrm{mg} /$ day contraindicated in pregnancy) and azithromycin in single $1 \mathrm{~g}$ oral dose. Second-line treatment regimens are 7 -day courses of erythromycin $(2 \times 500 \mathrm{mg} /$ day), levofloxacin (500 mg once daily) or ofloxacin $(2 \times 200 \mathrm{mg} /$ day $)$; the latter two regimens are contraindicated in pregnancy.

- The recommended treatment in pregnant and breast-feeding women is azithromycin at $1 \mathrm{~g}$ (first-line treatment) or amoxicillin at $500 \mathrm{mg}$ three times a day for 7 days, erythromycin $500 \mathrm{mg}$ four times a day for 7 days (both antibiotics in second-line treatment) or josamycin $500 \mathrm{mg}$ three times a day or 1,000 mg twice a day for 7 days (third-line treatment); all the antibiotics are used orally.

- In cases of suspected or confirmed Mycoplasma genitalium infection the therapeutic regimen is azithromycin at $500 \mathrm{mg}$ on the first day, followed by $250 \mathrm{mg} /$ day for 4 consecutive days.

- All sexual partners within the preceding 6 months of the onset of symptoms or diagnosis should be evaluated and treated.

- The majority of patients treated with first-line regimens do not require a laboratory test to wymaz z przedsionka pochwy u kobiet (także pobrany samodzielnie).

- Zalecane są NAATs zaaprobowane przez Agencję ds. Żywności i Leków oraz wykrywające różne warianty C. trachomatis.

- Dostępne komercyjnie „szybkie testy przyłóżkowe” nie są rekomendowane w Europie.

- W przypadku wykrycia zakażenia C. trachomatis w obrębie gardła lub odbytnicy u homoseksualnych mężczyzn zaleca się dalsze typowanie w kierunku serotypów LGV. W Polsce możliwości takiego typowania są dotąd ograniczone.

- Nie jest wskazane wykrywanie przeciwciał przeciwko C. trachomatis w surowicy - ani do badań przesiewowych, ani w diagnostyce niepowikłanych przypadków zakażeń.

- Należy dążyć do wdrożenia programu dobrowolnych badań przesiewowych w kierunku zakażeń C. trachomatis u młodych (<25. roku życia), aktywnych seksualnie osób, idealnie raz do roku.

- Pacjenci z dodatnim wynikiem badania w kierunku C. trachomatis powinni być zbadani w kierunku kiły, rzeżączki i zakażenia HIV.

\section{LECZENIE}

- Wskazaniem do leczenia jest wykrycie C. trachomatis za pomocą zalecanych metod w materiale pobranym od pacjenta. Zalecane jest także leczenie na podstawie przesłanek epidemiologicznych (zakażenie u partnera) oraz w przypadkach objawów zapalenia układu moczowo-płciowego.

- Za leczenie pierwszego rzutu uważa się zarówno doustną 7-dniową kurację doksycykliną $(2 \times 100$ mg/ dobę - przeciwwskazana w ciąży), jak i jednorazową dawkę $1 \mathrm{~g}$ azytromycyny. Terapię drugiego rzutu stanowi: erytromycyna $(2 \times 500 \mathrm{mg} /$ dobę), lewofloksacyna (500 mg raz dziennie) lub ofloksacyna $(2 \times 200 \mathrm{mg} /$ dobę $)$ - wszystkie terapie trwają 7 dni, dwie ostatnie są przeciwwskazane w ciąży.

- U kobiet w ciąży i karmiących piersią rekomenduje się leczenie azytromycyną $1 \mathrm{~g}$ (leczenie pierwszego rzutu) lub amoksycyliną $500 \mathrm{mg}$ trzy razy dziennie przez 7 dni, erytromycyną 500 mg cztery razy dziennie przez 7 dni (oba antybiotyki jako leczenie drugiego rzutu) lub josamycyną 500 mg trzy razy dziennie lub 1000 mg dwa razy dziennie przez 7 dni; (leczenie trzeciego rzutu); wszystkie antybiotyki podaje się doustnie.

- Przy podejrzeniu lub potwierdzeniu zakażenia Mycoplasma genitalium schemat terapeutyczny to: $500 \mathrm{mg}$ azytromycyny pierwszego dnia, a następnie $250 \mathrm{mg} /$ dobę przez kolejne 4 dni.

- Należy zbadać i leczyć wszystkich partnerów seksualnych z ostatnich 6 miesięcy od początku objawów lub stwierdzenia zakażenia. 
confirm the success of treatment (test-of-cure - TOC). However TOC should be performed in pregnant women, patients with complicated infections or persistent symptoms. After second-line treatment TOC should be performed 4 weeks after the completion of therapy.

- All cases of C. trachomatis infection should be reported within 24 hours, using an appropriate form, to the state or border sanitary inspector (Act of 5 December 2008 on preventing and combating human infections and infectious diseases, Polish Journal of Laws - Dz.U. 2008 no. 234 item 1570 as amended).
- Po zastosowaniu leczenia pierwszego rzutu u większości pacjentów nie jest wymagane wykonanie badania laboratoryjnego potwierdzającego wyleczenie (test of cure - TOC). Badanie takie należy wykonać u kobiet w ciąży, pacjentów z zakażeniami powikłanymi lub jeśli utrzymują się objawy. Po zastosowaniu leczenia drugiego rzutu TOC należy wykonać 4 tygodnie po zakończeniu terapii.

- Wszystkie przypadki zakażenia C. trachomatis należy zgłosić w ciągu 24 godzin na odpowiednim formularzu do państwowego lub granicznego inspektora sanitarnego (,'Ustawa z dnia 5 grudnia 2008 r. o zapobieganiu oraz zwalczaniu zakażeń i chorób zakaźnych u ludzi”, Dz.U. 2008 nr 234 poz. 1570 z późn. zm.).

\section{References}

\section{Piśmiennictwo}

1. European Centre for Disease Prevention and Control.: Annual Epidemiological Report 2016 - Chlamydia. Stockholm: ECDC; 2016. Available at: http://ecdc.europa.eu/en/healthtopics/chlamydia/Pages/Annual-epidemiological-report-2016.aspx

2. Rozporządzenie Ministra Zdrowia z dnia 10 lipca 2013 r. w sprawie zgłoszeń podejrzenia lub rozpoznania zakażenia, choroby zakaźnej lub zgonu z powodu zakażenia lub choroby zakaźnej: Dz.U. 2013 poz. 848. Available at: http://isap.sejm.gov. pl/DetailsServlet?id=WDU20130000848

3. Lanjouw E., Ouburg S., de Vries H.J., Stary A., Radcliffe K., Unemo M.: 2015 European guideline on the management of Chlamydia trachomatis infections. Int J STD AIDS 2016, 27, 333-348.

Received: 13.04 .2017

Accepted: 6.05 .2017

Otrzymano: $13.04 .2017 \mathrm{r}$.

Zaakceptowano: $6.05 .2017 \mathrm{r}$. 